Gut, 1978, 19, 403-407

\title{
Electron immunohistochemical evidence for the human intestinal I cell as the source of CCK
}

\author{
Alison M. J. BUCHAN, JULiA M. POLAK, E. SOlCiA, C. CAPElla, \\ D. HUDSON, AND A. G. E. PEARSE
}

\begin{abstract}
From the Department of Histochemistry and Endocrine Unit, Royal Postgraduate Medical School, Hammersmith Hospital, London, and Centre of Histopathology, Histochemistry and Ultrastructure, University of Pavia at Varese, Italy
\end{abstract}

SUMMARY Evidence was obtained by the use of alternate semithin-thin serial sections for light and electron microscopy that the I cell is the source of CCK-PZ. The antibodies used were raised to a synthetic fragment of the mid part (9-20) of the (1-33) CCK-PZ molecule, and were thus free from any contamination with cross-reacting subpopulations of antibodies that might bind to gastrin.

Cholecystokinin-pancreozymin (CCK-PZ), a biologically active peptide, has been shown by immunohistochemistry to be present in the duodenal and jejunal areas of the human small intestine (Buffa et al., 1976; Polak et al., 1975). Clearly it is important to identify the endocrine cell responsible for the synthesis and storage of this hormone. It has been previously suggested that the ultrastructurally identified I cell is the source of CCK-PZ (Solcia et al., 1975). Early evidence for this association was circumstantial, in that the distribution of CCK-PZ activity and the distribution of endocrine cells immunostained with antibodies raised to the whole molecule of CCK-PZ corresponded to the distribution of the morphologically identified I cells (Polak et al., 1975; Buffa et al., 1976). Although the I cell origin of CCK-PZ was confirmed to some extent by preliminary results using the semithin-thin sectioning method (Polak et al., 1975), it was necessary to produce more conclusive evidence for the final identification of the cellular origin. There is, unfortunately, cross-reactivity between gastrin and antisera raised to the whole molecule of CCK-PZ because the two peptides share a C-terminal sequence (Jorpes and Mutt, 1973). Thus antibodies raised to the whole CCK-PZ molecule will contain a population of antibodies capable of binding this Cterminal sequence and therefore cross-reacting with any gastrin present in the tissue. This has been a

Address for correspondence: Dr J. M. Polak, Department of Histochemistry, RPMS, Hammersmith Hospital, London W12 0HS.

Received for publication 21 November 1977 major problem in the immunohistochemical identification of CCK-PZ, as cells containing gastrin are also found in the duodenal mucosa (Polak et al., 1975; Buffa et al., 1976).

Immunohistochemical techniques use much higher concentrations of antibodies than radioimmunoassay techniques, so it is possible for even a subpopulation of antibodies to create a positive staining result. Initially, the only means of abolishing this staining effect was to absorb the CCK-PZ antibodies with pentagastrin to remove the crossreacting antibodies while leaving the specific antibodies unaffected (Buffa et al., 1976).

In this study we have achieved the complete identification of the CCK-PZ cell in the human small intestine by use of antibodies to a synthetic fragment of CCK-PZ (9-20) which lacks the sequence homology with gastrin.

\section{Methods}

Twenty-five surgical samples of human antrum, duodenum, and jejunum were fixed by two techniques: (1) $2.5 \%$ purified glutaraldehyde in $0.05 \mathrm{M}$ phosphate buffer $\mathrm{pH} \mathbf{7 \cdot 3}$ for five minutes (used for immunohistochemical techniques), and (2) $2.5 \%$ glutaraldehyde in $\mathbf{0 . 1} \mathrm{M}$ phosphate buffer $\mathrm{pH} \mathbf{7 \cdot 3}$ for two hours, postfixed in osmium tetroxide (for conventional electron microscopy). The samples were then dehydrated through graded alcohols and embedded in Araldite. Sections were taken serially, first $1 \mu$ then $60 \mathrm{~nm}$. The $1 \mu$ sections were used for the immunohistochemical technique using an indirect immunofluorescent method as outlined 
below. The adjacent $60 \mathrm{~nm}$ sections were floated onto copper grids for counterstaining with uranyl acetate and lead citrate.

The Araldite was removed from the $1 \mu$ sections by saturated $\mathrm{NaOH}$ in ethanol. The sections were rehydrated through graded alcohols, then the indirect immunofluorescent technique of Coons, Leduc and Connolly (Coons et al., 1955) was applied. The first layer was CCK-PZ (9-20) antiserum at a dilution of 1:400 for a 24 hour incubation. The second layer was FITC goat antirabbit conjugate (Hyland) for one hour at room temperature. Various controls were applied, including prior absorption of the antibodies with the following antigens: CCK-PZ (1-33) $(99 \%$ pure from Professor V. Mutt 3000Ivy dog units per mg), CCK-PZ (9-20) synthetic (Polak et al., 1977), CCK-PZ (26-33) Dr M. Ondetti, Squibb Institute for Medical Research, New Jersey, USA) Gastrin 1-17 synthetic (ICI), somatostatin (synthetic, cyclic from Beckman Bioproducts), GIP-porcine GIP $99.9 \%$ pure from Professor J. C. Brown, Vancouver, and glucagon (10units/10 mg, Eli Lilly, Indianapolis, USA). The dodecapeptide Met-Ile-Lys-Asn-Leu-Gln-Ser-Leu-AspPro-Ser-His, corresponding to the midportion (9-20) of the CCK-PZ molecule, has been synthesised (Polak et al., 1977) and used to raise specific antibodies.

Rabbits were injected with $100 \mu$ g dodecapeptide coupled to ovalbumin by the glutaraldehyde method in complete Freund's adjuvant. Animals were injected at three monthly intervals (Polak et al., 1977) for nine to 12 months. The specificity of the antibodies was tested by absorption with the peptides before staining as already stated. It was also checked by the recently developed Enzyme Linked Immunosorbent Assay (ELISA) (Voller et al., 1976), a technique applied here for the first time to gut hormones, although it has been extensively used in other fields.

We measured the diameter of all granules found in the CCK-PZ cells identified ultrastructurally by immunocytochemistry and in I cells identified by conventional electron microscopy. The mean diameter was calculated and corrected for sectioning artefacts with the formula $D=(4 / \pi)$. $\bar{d}$ (Baetens et al., 1976).

\section{Results}

Scattered endocrine cells within the duodenal and jejunal mucosa were specifically stained by the CCK-PZ (9-20) antibodies in semithin sections (Fig. 1a).

Quenching of the antibody to the mid portion fragment of CCK-PZ occurred only with CCK-PZ
(1-33) and (9-20) molecules and not with gastrin (1-17), glucagon, somatostatin, GIP, and 26-33 CCK-PZ octapeptide. The ELISA technique showed that the antibodies raised to the synthetic fragment of CCK-PZ tested at the same dilution as used in the immunocytochemical staining, bound only to the 1-33 and 9-20 CCK-PZ sequences and not to the other peptides. A sample of an antiserum raised to the whole CCK-PZ (1-33) molecule (Polak et al., 1975) showed binding to both the CCK-PZ peptides and to gastrin 1-17. In addition, the anti-CCK-PZ (9-20) serum, when applied to sections of human antrum failed to show any positive staining, whereas serial sections stained with gastrin 1-17 antisera showed numerous positive cells. The CCK-PZ cells which were identified in the semithin sections were identified at the ultrastructural level on consecutive sections (Fig. 1b and c). They constituted a homogeneous population of cells with mainly round, sometimes angular, relatively dense granules averaging $260 \mathrm{~nm}(\mathrm{SD} \pm 22 \mathrm{~nm})$ in size, corrected values: $330 \mathrm{~nm} \quad(700$ granules from nine cells measured). I cells as identified by conventional electron microscopy (Fig. 2) also showed mainly round, compact granules with closely applied membrane, measuring $253 \mathrm{~nm}$ (SD $\pm 58 \mathrm{~nm}$ ) corrected values $322 \mathrm{~nm}$ (604 granules measured from six cells). The two measurements did not differ significantly. Although some $G$ cells with vesicular granules of floccular content were found by conventional electron microscopy in the human duodenum, none of the cells reacting with the specific CCK-PZ antibodies resembles $G$ cells.

\section{Discussion}

These results show that, when structurally similar hormones with overlapping properties are found in the same area of the gut, the complexity of the situation can be resolved by combined light and electron immunohistochemical techniques using antibodies to fragments of one hormone molecule which lack a common sequence with other peptides.

Immunocytochemical findings using the specific CCK-PZ (9-20) antibodies permitted the staining of the CCK-PZ cell without interference from gastrin cells.

Although C-terminal peptides of CCK-PZ (which are reported to be quite abundant in the small intestine (Larsson et al., 1978; Rehfeld, 1978) were not recognised by the antibodies in control tests, antibodies to the whole 1-33 CCK-PZ molecule proved heavily reactive and ensured detection of CCK-PZ cells, although any gastrin cells present would of course be stained in addition. The ultrastructural features of most of the cells stained by 

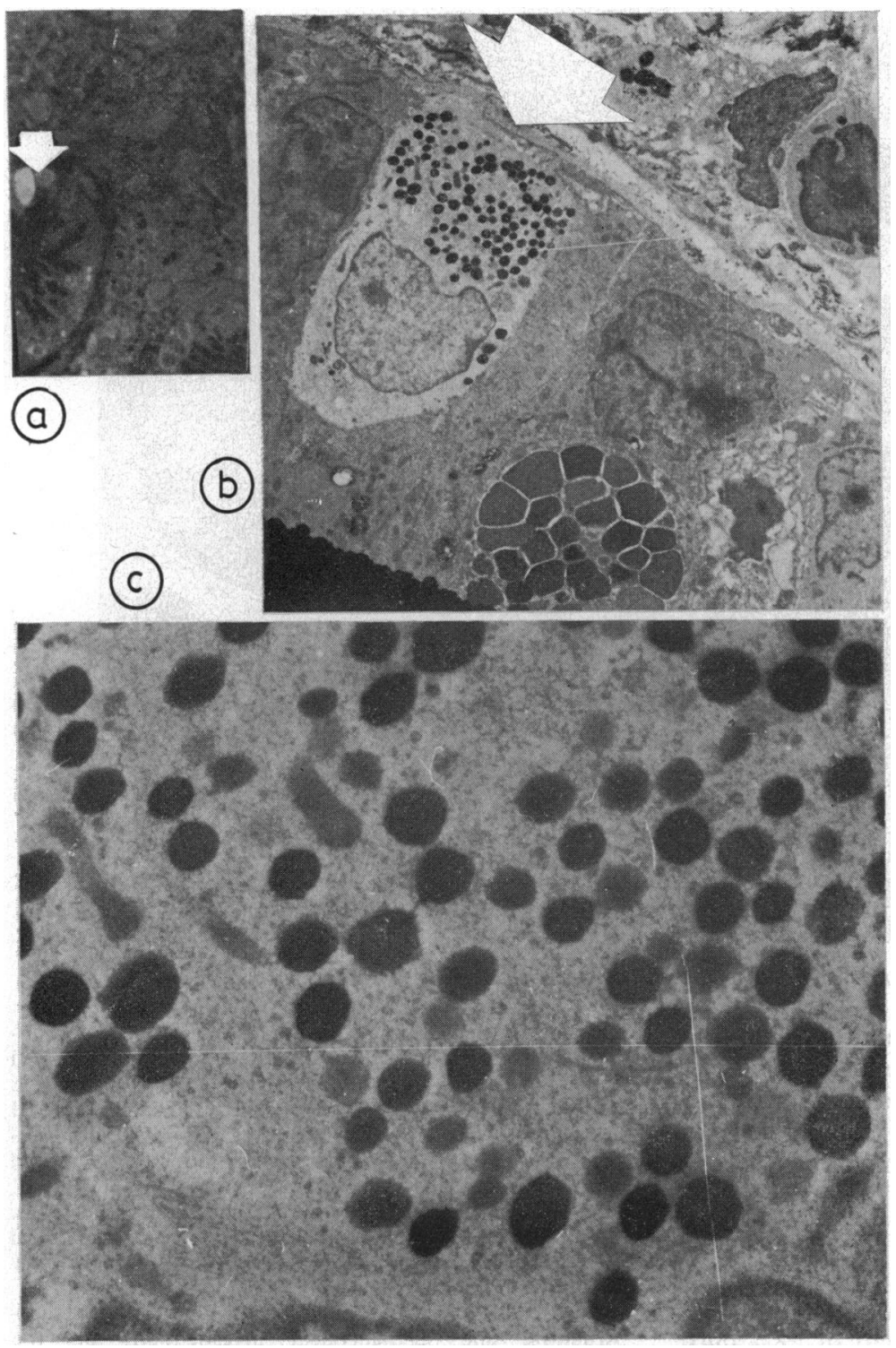

Fig. 1 (a) CCK-PZ cell of the human jejunal mucosa stained with specific antibodies to CCK-PZ fragment 9-20, $\times 625$. (b) Electron micrograph of the same cell, $\times 4000$.

(c) Detail of the same to show characteristic secretory granules, $\times 20,000$. this antibody corresponded closely to those already reported for human I cells. Although it is possible that cells storing only the C-terminal fragments with no 9-20 CCK-PZ content might have escaped detection in our immunohistochemical staining using the CCK-PZ 9-20 antibodies, it must be stressed that the existence of such cells has never been demonstrated. The I cell was first identified in the dog (Bussolati et al., 1971) as a cell with granules of size and structural pattern intermediate between those of $S$ and $L$ cells, which are reputed to produce respectively secretin and glucagon-like immunoreactivity (GLI). In man, the identification of I cells on ultrastructural groundsalone is made more difficult by the smaller size of human L cell granules; however, granules of I cells are slightly more electron dense than those of $\mathrm{L}$ cells and lack their thin argyrophil halo (Capella et al., 1972). Moreover, human I cells-like CCK-PZ cells (Polak et al., 1975; Buffa et al., 1976) and unlike L (GLI) cells (Grimelius et al., 1976)-are well represented in the duodenum but lacking in the colon and rectum (Capella et al., 1976). The results of the present immunohistochemical investigation allow us to 


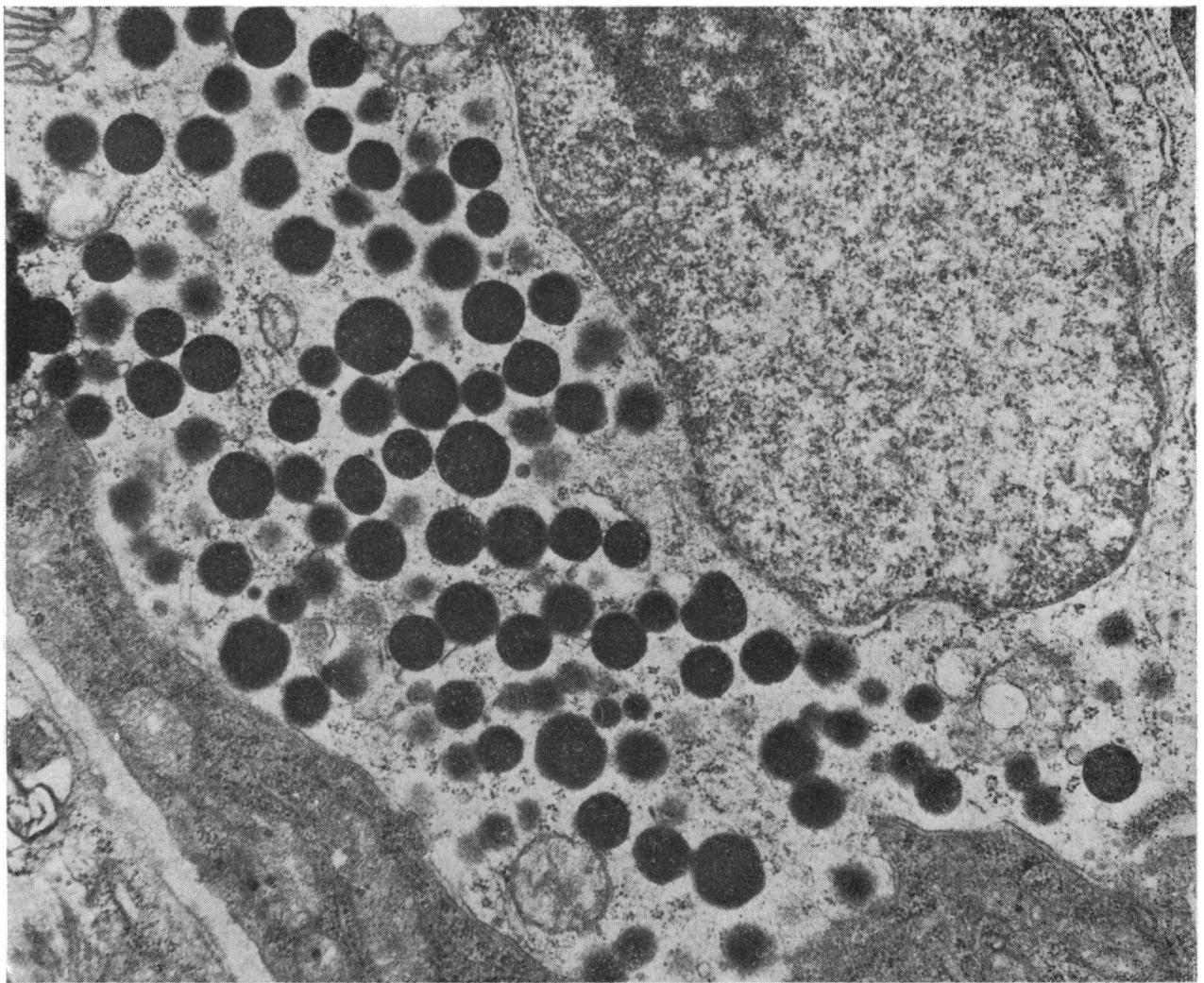

Fig. 2 Conventional electron microscopy of an I cell showing detail of the secretory granules, $\times 20,000$.

confirm the ultrastructural localisation of the human I cell on a sounder basis and to identify it with the CCK-PZ cell of light microscopy. It should now be possible to carry out ultrastructural studies of this cell in experimental and pathological conditions.

We are very grateful to $\mathrm{Dr} \mathrm{A}$. Voller and his colleagues at the Nuffield Institute of Comparative Medicine for their help in setting up the ELISA system for use in our study. The gift of $99 \%$ pure CCK-PZ from Professor V. Mutt is also gratefully acknowledged. This work was made possible with the aid of grants from the Medical Research Council, the Cancer Research Campaign, the Volkswagenwerk Stiftung (Hannover), and Consigilo Nationale delle Ricerche (Rome).

\section{References}

Baetens, D., Rufener, C., Srikant, B. C., Dobbs, R., Unger, R., and Orci, L. (1976). Identification of glucagonproducing cells (A cells) in dog gastric mucosa. Journal of Cell Biology, 69, 455-464.

Bloom, S. R., and Polak, J. M. (1977). The new peptide hormones of the gut. In Progress in Gastroenterology, Edited by G. J. Glass, Grune and Stratton: New York.
Buffa, R., Solcia, E., and Go, V. L. W. (1976). Immunohistochemical identification of the cholecystokinin cell in the intestinal mucosa. Gastroenterology, 70, 528-532.

Bussolati, G., Capella, C., Solcia, E., Vassallo, G., and Vessadini, P. (1971). Ultrastructural and immunofluorescent investigations on the secretin cell in the dog intestinal mucosa. Histochemie, 26, 218-227.

Capella, C., Solcia, E., Frigerio, B., and Buffa, R. (1976). Endocrine cells of the human intestine. An ultrastructural study. In Endocrine Gut and Pancreas, pp. 43-59. Edited by T. Fujita, Elsevier: Amsterdam.

Capella, C., Solcia, E., and Vassallo, G. (1972). Ultrastructural and histochemical investigations on the endocrine cells of the intestinal mucosa. In Endocrinology, vol. 71 , pp. $282-290$, Edited by S. Taylor. Heinemann: London.

Coons, A. H., Leduc, E. H., and Connolly, J. M. (1955). Studies on antibody production 1. A method for the histochemical demonstration of specific antibody and its application to a study of the hyperimmune rabbit. Journal of Experimental Medicine, 102, 49-60.

Grimelius, L., Capella, C., Buffa, R., Polak, J. M., Pearse, A. G. E., and Solcia, E. (1976). Cytochemical and ultrastructural differentiation of enteroglucagon and pancreatictype glucagon cells of the gastrointestinal tract. Virchows Archiv. B. Cell Pathology. 20, 217-228.

Jorpes, J. E. and Mutt, V. (1973). Secretin and cholecystokinin (CCK). In Secretin, Cholecystokinin, Pancreozymin and Gastrin, pp. 1-179. Edited by J. E. Jorpes and V. Mutt, Springer: Berlin. 
Larsson, L.-I. (1978). Evolution of CCK-like hormones. In Gut Hormones. Pp. 68-74. Edited by S. R. Bloom. Churchill Livingstone: Edinburgh.

Polak, J. M., Pearse, A. G. E., Bloom, S. R., Buchan, A. M. J., Rayford, P. L., and Thompson, J. C. (1975). Identification of cholecystokinin-secreting cells. Lancet, 2, 1016-1018.

Polak, J. M., Pearse, A. G. E., Szelke, M., Bloom, S. R., Hudson, D., Facer, P., Buchan, A. M. J., Bryant, M. G., Christophodes, N., and MacIntyre, I. (1977). Specific immunostaining of CCK cells by use of synthetic fragment antisera. Experientia, 33, 762-763.

Rehfeld, J. F. (1978). Multiple molecular forms of CCK. In Gut Hormones. Pp. 213-218. Edited by S. R. Bloom, Churchill Livingstone: Edinburgh.

Solcia, E., Capella, C., Vassallo, G., and Buffa, R. (1975). Endocrine cells of the gastric mucosa. International Review of Cytology, 42, 223-286.

Voller, A., Bidwell, D. E., and Bartlett, A. (1976). Enzyme immunoassays in diagnostic medicine. Bulletin of the World Health Organisation, 53, 55-65. 